(c) American Dairy Science Association, 2005.

\title{
Actions and Outcomes of Wisconsin Dairy Farms Completing Milk Quality Teams
}

\author{
A. C. O. Rodrigues and P. L. Ruegg \\ Department of Dairy Science, University of Wisconsin, Madison 53706
}

\section{INTRODUCTION}

Bulk milk somatic cell count (BMSCC) is associated with prevalence of subclinical mastitis (Eberhart et al., 1982; Harmon, 1994). At the herd level, BMSCC $<200,000$ cells $/ \mathrm{mL}$ indicates satisfactory control of subclinical mastitis (Jayarao and Wolfgang, 2003). Herds having high BMSCC often have more infections caused by contagious pathogens (Fenlon et al., 1995; Barkema et al., 1998). These pathogens are characterized by subclinical infections of long duration and they often result in chronic increases in BMSCC.

Control of mastitis is based on prevention of new infections and elimination of existing infections (Ruegg, 2003). The 5-point plan (postmilking teat disinfection, universal dry cow therapy, appropriate treatment of clinical cases, culling of chronically infected cows, and regular milking machine maintenance) is successful when adopted to control contagious pathogens. Widespread implementation of many good management practices, however, is often difficult to achieve (Giger et al., 1994; Payne et al., 1999).

Mastitis control programs can be used to increase milk production and to improve profitability (Payne et al., 1999). Several types of mastitis control programs have been reported (Morin et al., 1993; Peters et al., 1994; Sischo et al., 1997; Sargeant et al., 1998). Each program has reported use of different approaches, but in general, programs focus on enhancing adoption of research-based practices and management principles that reduce the level of exposure to mastitis pathogens.

Dairy professionals often act as educators to encourage clients to implement new technologies (Peters et al., 1994; Sischo et al., 1997). Formation of teams that include extension and agricultural professionals helps farmers achieve goals more rapidly (Weinand and Conlin, 2003). Management teams can help farmers focus on specific problems and supply resources that encourage problem solving. Further, team members have the opportunity to share experiences and learn from each other.

Since 2001, Wisconsin dairy farms have had the opportunity to enroll in a mastitis control program ("Milk Money") designed to provide producers with a comprehensive approach to manage milk quality (companion 
article; Rodrigues et al., 2005). The program is a voluntary program designed to encourage the production of high quality milk, and is based on formation of a selfselected team of advisors. During the program, farmers meet with their team 4 times (usually at 4 consecutive monthly meetings) to focus specifically on issues that affect milk quality. Farms define their own goals and use the team and program materials to help prioritize management changes that will help them reach their goals. The objective of the present study was to evaluate actions and outcomes of farms that had completed the milk quality program.

\section{MATERIALS AND METHODS}

\section{Data}

Enrollment and data collection from herds enrolling in the program is described in the companion article (Rodrigues et al., 2005). In brief, information was obtained from Wisconsin dairy farms $(n=113)$ that completed a statewide team-based milk quality program from fall 2001 to spring 2004. Data were collected by team leaders (dairy professionals and producers). Information about the herd, team activities, and management practices were collected using standardized program materials (available at http://www.uwex.edu/ milkquality/programs/index.htm). Sources of data included milk plant receipts, farm records, DHI reports ( $\mathrm{n}=86$ herds), and farmer recall. Data were sent to the university in preaddressed envelopes, entered in a database, and checked for reliability. When program forms were missing, team leaders were contacted to supply the missing information.

During each team meeting, dairy farmers identified milk quality goals, set target dates to reach the goals, created an action plan, and assigned responsibility for specific tasks. Data were recorded on standardized forms composed of open-ended questions and used in subsequent meetings to address farm objectives. For the purpose of analysis, goals and actions were categorized into specific management areas (Tables 1 and 2). During the fourth team meeting, participants used an assessment form to evaluate progress and accomplishment of goals.

\section{Definition of Variables}

The definition of clinical mastitis was farm-specific and was not standardized for this study. Estimated monthly rate of clinical mastitis was calculated as the total number of monthly clinical mastitis cases reported for the preceding month divided by the average monthly number of lactating cows. Duration of milk discard for clinical mastitis was estimated as the total number of days that milk from a clinical mastitis case was withheld from the bulk tank. For herds enrolled in DHI, prevalence and incidence of subclinical mastitis were obtained from DHI data and represented the percentage of cows having SCS $>4$ at test day and the percentage of cows with SCS $>4$ for first time in current lactation, respectively.

\section{Statistical Analyses}

Statistical significance was declared at $P \leq 0.05$. As previously described (Rodrigues et al., 2005), herds were characterized by facility type (free stall or stallbarn) and BMSCC at the beginning of the program [low $(<250,000 \mathrm{cell} / \mathrm{mL})$; medium ( 250,000 to 400,000 cells/ $\mathrm{mL})$; and high $(>400,000$ cells $/ \mathrm{mL})]$. Categories of goals and actions were assessed by facility type and initial BMSCC using Cochran-Mantel-Haenszel statistics (SAS Institute, 2001).

Use of selected management practices and herd characteristics were compared between the first and the last team meeting. Farm was the experimental unit. The BMSCC and standard plate counts were transformed to base 10 logarithms for analysis. Categorical variables were analyzed using McNemar's test (SAS Institute, 2001), and continuous variables were analyzed using GLM (SAS Institute, 2001) in a model containing year, season, and number of lactating cows.

For herds that did not report the use of a given management practice at the first meeting, the differences in adoption of management practices between the first and the last team meeting were stratified by management practice and by categories (facility type and initial BMSCC), and analyzed using Cochran-Mantel-Haenszel statistics (SAS Institute, 2001). For analysis by BMSCC, the smallest BMSCC category was used as the basis for comparison. Differences in herd performance between the first and the last team meeting were analyzed by categories (facility type and initial BMSCC) using PROC GLM (SAS Institute, 2001). Models included year, season, and number of lactating cows; separate models were developed for each category (facility type and initial BMSCC).

\section{RESULTS}

\section{Milk Quality Program}

Of originally enrolled herds ( $\mathrm{n}=180), 113(62.8 \%)$ completed the program before analysis began. Enrollment in this program is ongoing, and most of the remaining herds $(n=67)$ enrolled in the program, but had not yet completed their fourth meeting. Mean and median duration of time between the first and fourth team meetings were 4.2 and $3.7 \mathrm{mo}$, respectively. The 
Table 1. Goal categories and specific goals listed by farms $(n=113)$ completing the milk quality improvement teams stratified by housing type.

\begin{tabular}{|c|c|c|c|c|}
\hline \multirow[b]{2}{*}{ Goal category/specific goal } & \multicolumn{2}{|c|}{ Facility type } & \multirow{2}{*}{$\begin{array}{l}\text { Odds } \\
\text { ratio }\end{array}$} & \multirow[b]{2}{*}{$P$} \\
\hline & Freestall & Stallbarn & & \\
\hline $\begin{array}{l}\text { Dry cow } \\
\text { Improve dry cow environment } \\
\text { Improve dry cow program }\end{array}$ & 2.8 & 3.3 & 1.19 & 0.762 \\
\hline $\begin{array}{l}\text { General management } \\
\text { Develop farm standard operating procedure } \\
\text { Improve communication } \\
\text { Improve record keeping }\end{array}$ & 3.6 & 6.6 & 1.89 & 0.152 \\
\hline $\begin{array}{l}\text { Herd performance } \\
\text { Increase milk production } \\
\text { Increase quality premium } \\
\text { Lower bulk milk SCC } \\
\text { Lower standard plate count }\end{array}$ & 34.5 & 44.3 & 1.51 & 0.040 \\
\hline $\begin{array}{l}\text { Hygiene } \\
\text { Improve cow hygiene } \\
\text { Improve facility hygiene } \\
\text { Reduce environmental pathogens in bulk milk }\end{array}$ & 4.8 & 2.2 & 0.45 & 0.159 \\
\hline $\begin{array}{l}\text { Mastitis control } \\
\text { Control contagious mastitis } \\
\text { Control environmental mastitis } \\
\text { Decrease clinical rate } \\
\text { Decrease fresh cow mastitis rate } \\
\text { Decrease mastitis cull rate } \\
\text { Decrease new infection rate } \\
\text { Define pathogen problem } \\
\text { Eradicate contagious pathogens } \\
\text { Improve mastitis detection }\end{array}$ & 32.5 & 23.5 & 0.64 & 0.040 \\
\hline $\begin{array}{l}\text { Milking } \\
\text { Adopt machine maintenance schedule } \\
\text { Develop standard operating procedures } \\
\text { Improve milker training } \\
\text { Increase milking efficiency }\end{array}$ & 15.8 & 13.7 & 0.84 & 0.523 \\
\hline $\begin{array}{l}\text { Teat } \\
\text { Improve teat score }\end{array}$ & 1.6 & 2.6 & 1.74 & 0.408 \\
\hline $\begin{array}{l}\text { Treatment } \\
\text { Analyze records } \\
\text { Develop protocol for treatment } \\
\text { Reduce discarded milk }\end{array}$ & 4.4 & 3.8 & 0.87 & 0.781 \\
\hline
\end{tabular}

average team was composed of 5.5 members (2 to 11$)$. Team leaders included extension professionals $(n=72)$, veterinarians $(\mathrm{n}=25)$, other agri-professionals $(\mathrm{n}=$ $13)$, and farm owners $(\mathrm{n}=3)$. Almost half of the teams (46.4\%) included a veterinarian, an extension agent, and a dairy plant field representative. Herds reported that subclinical mastitis (12.5\%), clinical mastitis $(27.3 \%)$, and quality premiums $(60.2 \%)$ were major areas for improvement that would increase their financial performance. A variety of critical management factors was identified, but environmental mastitis and milking routine were the most commonly cited (Table 3 ).

At the completion of the program, of herds responding to the question regarding achievement of goals $(\mathrm{n}=96)$, 60 herds $(62.5 \%)$ reported that they had achieved their milk quality goals. Herds reported that lack of time (48.6\%), other farm problems (16.3\%), lack of focus (16.2\%), seasonal influences (13.5\%), and choice of goals
(5.4\%) were possible reasons for failure to meet goals. Nearly all $(98 \%)$ of the herds agreed that they had selected the right team members, and $99.1 \%$ agreed that teams were useful for improving milk quality. Most herds $(82.9 \%)$ planned to continue team meetings and $32.1 \%$ planned to change or add milk quality goals.

\section{Goals and Actions}

A total of 283 goals were listed for the 113 farms (2.5 goals per farm). Goals included general herd performance (listed by $38.3 \%$ of herds), procedures for mastitis control (28.6\%), milking performance $(14.9 \%)$, and issues such as general management, hygiene, treatment, dry cow management, or teat health $(<5 \%)$.

A total of 554 actions were listed (4.9 actions per farm). Actions included milking activities (28.8\%), culture of milk samples (20.8\%), assessment of farm man- 
Table 2. Action categories and description of actions listed by 113 dairy farms completing milk quality improvement teams stratified by housing type.

\begin{tabular}{|c|c|c|c|c|}
\hline \multirow[b]{2}{*}{ Action category/description } & \multicolumn{2}{|c|}{ Facility type } & \multirow{2}{*}{$\begin{array}{l}\text { Odds } \\
\text { ratio }\end{array}$} & \multirow[b]{2}{*}{$P$} \\
\hline & Freestall & Stallbarn & & \\
\hline $\begin{array}{l}\text { Data } \\
\text { Analyze farm data using computers } \\
\text { Enroll in DHI udder health report } \\
\text { Group herd by production } \\
\text { Start DHI test for SCC }\end{array}$ & 5.6 & 6.0 & 1.08 & 0.799 \\
\hline $\begin{array}{l}\text { General management } \\
\text { Assess ventilation } \\
\text { Calculate farm economics } \\
\text { Check stray voltage } \\
\text { Evaluate facility maintenance } \\
\text { Group herd by production } \\
\text { Monitor fresh cows } \\
\text { Remodel facility } \\
\text { Review farm standard operating procedures } \\
\text { Schedule employee meetings }\end{array}$ & 13.6 & 10.4 & 0.74 & 0.153 \\
\hline $\begin{array}{l}\text { Hygiene } \\
\text { Dock tails } \\
\text { Evaluate dry lot cleaning } \\
\text { Remove udder hair using heat } \\
\text { Score udder hygiene }\end{array}$ & 4.8 & 1.4 & 0.27 & 0.006 \\
\hline $\begin{array}{l}\text { Mastitis } \\
\text { Analyze records } \\
\text { Record clinical cases } \\
\text { Segregate infected cows } \\
\text { Use of California mastitis test }\end{array}$ & 11.4 & 9.0 & 0.77 & 0.255 \\
\hline $\begin{array}{l}\text { Milking } \\
\text { Analyze system } \\
\text { Develop standard operating procedures } \\
\text { Modify milking routine } \\
\text { Observe milking routine } \\
\text { Train milkers } \\
\text { Utilize milker incentive program }\end{array}$ & 29.3 & 30.0 & 1.03 & 0.840 \\
\hline $\begin{array}{l}\text { Milk culture } \\
\text { At dry-off } \\
\text { Bulk tank } \\
\text { Clinical cows } \\
\text { Fresh cows } \\
\text { Heifers } \\
\text { High SCC cows } \\
\text { Whole herd }\end{array}$ & 18.4 & 25.1 & 1.49 & 0.017 \\
\hline $\begin{array}{l}\text { Other culture } \\
\text { Bedding } \\
\text { Milking machine }\end{array}$ & 1.4 & 0.0 & - & - \\
\hline $\begin{array}{l}\text { Teat } \\
\text { Score teat ends }\end{array}$ & 3.3 & 3.8 & 1.17 & 0.682 \\
\hline $\begin{array}{l}\text { Treatment } \\
\text { Analyze records } \\
\text { Modify dry cow therapy } \\
\text { Record treatments } \\
\text { Set up protocol } \\
\text { Treat prefresh cows } \\
\text { Utilize gram-negative core vaccine }\end{array}$ & 11.8 & 15.0 & 1.32 & 0.166 \\
\hline
\end{tabular}

agement (13.5\%), treatment and prevention of mastitis (13.1\%), specific activities for mastitis control (10.4\%), analysis of farm data (5.6\%), and issues related to hygiene, teat health, or culture of environmental sample $(\leq 3.0 \%)$.

Facility type. No overall association was detected between facility type and selection of milk quality goals $\left(\chi^{2}=1.2 ; P=0.955\right)$. However, milk quality teams with herds housed in stallbarns were more likely to adopt goals related to herd performance than teams with herds housed in freestalls (Table 1). Herd performance goals included: fewer BMSCC (listed by $83.7 \%$ of herds), increase milk production (8.2\%), fewer bacterial counts $(5.2 \%)$, and more milk quality premiums $(2.9 \%)$. Teams 
Table 3. Frequency of critical factors for the milk quality program reported by 113 Wisconsin dairies.

\begin{tabular}{ll}
\hline Factor & Frequency, \% \\
\hline Environmental mastitis & 70.8 \\
Milking routine & 60.2 \\
Clinical mastitis & 49.5 \\
Milking system & 47.8 \\
Treatment protocols & 44.2 \\
Cow/parlor hygiene & 39.8 \\
Teat end quality & 37.2 \\
Dry cow program & 36.3 \\
Milker training & 32.7 \\
Farm records & 32.7 \\
Contagious mastitis & 29.2 \\
Standard operating procedures & 29.2 \\
\hline
\end{tabular}

working with herds housed in stallbarns reported less interest in specific mastitis control goals than teams working with herds housed in freestalls (Table 1). Specific goals related to mastitis control focused on decreasing the rate of clinical mastitis (listed by $37.7 \%$ of herds), controlling contagious pathogens (21.3\%), decreasing new infections (10.4\%), defining mastitis pathogens (10.1\%), improving mastitis detection (7.6\%), and specific goals related to decreasing the rate of fresh cow mastitis, and decreasing the mastitis cull rate or controlling environmental mastitis $(\leq 5 \%)$.

No overall association was found between facility type and adoption of actions $\left(\chi^{2}=0.02 ; P=0.960\right)$. In contrast, operators of freestalls were approximately half as likely to submit milk samples for culturing than were operators of stallbarns (Table 2). The category of milk culture included culturing milk obtained from bulk tank (listed by $36.7 \%$ of herds), culturing milk obtained from cows with clinical mastitis (31.4\%), culturing milk obtained from cows with high SCC (29.9\%), and $\leq 5 \%$ was related to culturing milk obtained from fresh cows, heifers, cows at dry-off, or the whole herd. Hygiene was assessed more often by operators of herds housed in freestalls than operators of herds housed in stallbarns (Table 2). Actions related to the assessment of hygiene included: udder hygiene scoring (36.8\%), evaluation of dry lot cleaning $(30.1 \%)$, use of heat to remove udder hair (26.9\%), and tail docking (6.2\%).

BMSCC. No overall difference was detected in the selection of milk quality goals by BMSCC at enrollment. However, team members working with herds having low BMSCC were more likely to list general management [odds ratio $(\mathbf{O R})=4.55 ; P=0.009$ ], dry cow management $(\mathrm{OR}=6.73 ; P=0.008)$, and teat health $(\mathrm{OR}=$ $8.82 ; P=0.021)$ as goal areas than were team members with herds having medium BMSCC. Development of farm standard operating procedures comprised $59.3 \%$ of general management goals and improvement of dry cow program comprised $63.6 \%$ of dry cow management goals. Herd performance goals tended $(P<0.10)$ to be less likely selected by teams categorized as having low BMSCC herds than categorized as having medium BMSCC herds $(\mathrm{OR}=0.64)$.

No overall association was detected between BMSCC at enrollment and actions planned by operators, but operators of herds having low BMSCC tended $(P=0.08)$ to submit milk samples for culture more often than operators of herds having medium BMSCC $(\mathrm{OR}=1.60)$. Assessment of hygiene $(\mathrm{OR}=0.29 ; P=0.085)$ and specific procedures for mastitis control $(\mathrm{OR}=0.58 ; P=$ 0.095 ) tended to be selected by fewer operators of low BMSCC herds than by operators of medium BMSCC herds.

\section{Management Practices}

Formation of milk quality teams was an effective method to encourage adoption of best management practices (Table 4). At the initiation of the program, many herds had already reported use of recommended milking procedures. Most teams reported that they used a complete milking routine, used a single towel per cow to dry udders, and wore gloves during milking. The number of people milking per shift and per month did not differ between the first and last meeting. Use of comprehensive dry cow therapy and monthly review of individual cow SCC records were largely reported at the first meeting. With the exception of the use of comprehensive dry cow therapy, adoption of all the other practices was increased $(P<0.03)$ at the end of the milk quality program. Interval between milking system updates tended $(P=0.09)$ to decrease $(\overline{\mathrm{X}}=-8.7$ mo). Herd management was more committed to discuss milk quality issues with their dairy professionals after the monthly meetings.

Facility type. For herds that did not use a given management practice at the fist meeting facility type was associated $\left(\chi^{2}=30.0 ; P<0.001\right)$ with overall adoption of management practices. Operators of herds housed in stallbarns were approximately half $(\mathrm{OR}=$ 0.45) as likely to adopt recommended management practices than were operators of herds housed in freestalls. Herds housed in stallbarns were less $(\mathrm{OR}=$ $0.36 ; P=0.050$ ) likely to develop a schedule for milking system analysis during milking than herds housed in freestalls. Percentage of adoption of a written treatment protocol by herds that did not have a written treatment protocol at the first meeting was 35.6 and $59.5 \%$, respectively, for herds housed in stallbarns and in freestalls. Operators of herds housed in stallbarns were less $(\mathrm{OR}=0.38 ; P=0.030)$ likely to have a written treatment protocol at the end of the program. Team members of herds housed in stallbarns tended $(\mathrm{OR}=$ 
Table 4. Differences in management practices of 113 Wisconsin dairy farms completing milk quality program.

\begin{tabular}{lllrr}
\hline Management practice & $\begin{array}{l}\text { Before } \\
\text { program }\end{array}$ & $\begin{array}{l}\text { After } \\
\text { program }\end{array}$ & $\begin{array}{l}\text { Adoption } \\
\text { rate }^{1}\end{array}$ & $P$ \\
\cline { 2 - 4 } & \multicolumn{2}{c}{$\%$} & & \\
Annual analysis of milking system during milking & 39.4 & 61.5 & 38.1 & $<0.001$ \\
Forestrip & 86.5 & 92.3 & 50.0 & 0.030 \\
Pre-dip & 87.5 & 97.1 & 84.6 & 0.004 \\
Have a complete milking routine ${ }^{2}$ & 76.9 & 85.6 & 54.2 & 0.030 \\
Dry udder using 1 towel per cow & 86.0 & 91.6 & 46.7 & 0.030 \\
Always wear gloves during milking & 70.1 & 82.2 & 50.0 & 0.003 \\
Have a written milking routine & 25.5 & 51.9 & 36.7 & $<0.001$ \\
Have a frequent training program for milkers & 14.0 & 31.1 & 22.5 & $<0.001$ \\
Record clinical mastitis & 52.6 & 91.8 & 84.8 & $<0.001$ \\
Culture all clinical mastitis cases & 13.3 & 31.4 & 29.7 & $<0.001$ \\
Culture bulk milk several times per year & 59.2 & 87.4 & 76.2 & $<0.001$ \\
Have requested Mycoplasma culture & 53.3 & 70.1 & 48.0 & 0.001 \\
Have a written treatment protocol for clinical mastitis & 16.4 & 54.8 & 47.1 & $<0.001$ \\
Treat all quarters of all cows at dry-off & 91.5 & 95.3 & 44.5 & 0.100 \\
Use California mastitis test & 67.6 & 80.0 & 47.1 & 0.003 \\
Review individual cow SCC records each month & 77.6 & 90.7 & 58.3 & $<0.001$ \\
Plan milk quality program with farm veterinarian & 19.8 & 84.0 & 81.2 & $<0.001$ \\
Discuss milk quality issues with dairy plant field rep & 42.1 & 78.0 & 69.4 & $<0.001$ \\
Have regular meetings between dairy plant field rep and & & & & \\
veterinarian to talk about milk quality improvement & 7.6 & 62.9 & 61.9 & $<0.001$ \\
\hline
\end{tabular}

${ }^{1}$ Percentage of adoption by herds not performing each practice at the first meeting.

${ }^{2}$ Defined as use of a milking routine that includes forestrip, pre-dip, dry, and post-dip.

0.36 and $\mathrm{OR}=0.41 ; P=0.06$ ) to be approximately half as likely to begin a frequent training programs for milkers or culture all clinical cases than team members of herds housed in freestalls. At the last team meeting, $72.5 \%$ of herds housed in stallbarns and $88.9 \%$ of herds housed in freestalls reported that they had discussed milk quality issues with the herd veterinarian. Operators of herds housed in stallbarns were less $(\mathrm{OR}=0.33$; $P=0.05$ ) likely to discuss milk quality issues with the herd veterinarian compared with operators of herds housed in freestalls.

BMSCC. For herds that had not adopted management practices before enrollment, no overall association was detected between BMSCC category at enrollment and adoption of management practices. In contrast, operators of herds that reported low BMSCC were less $(\mathrm{OR}=0.20 ; P<0.03)$ likely to begin a milk quality plan with their veterinarian than were operators of herds that reported high BMSCC. Percentages of nonadopting herds that began discussing milk quality with their herd veterinarian at the end of the program were 64.7 and $90.3 \%$, respectively, for herds reporting low and high BMSCC.

\section{Performance Outcomes}

Formation of milk quality teams resulted in changes in herd performance (Table 5). Most of the standard measurements of milk quality improved during the program. Overall, BMSCC and bacterial count were re- duced by 20.2 and $28.4 \%$, respectively, compared with the first meeting. Indices of clinical and subclinical mastitis were improved $(P<0.033)$. Cull rates decreased at the end of the program. At the last meeting, estimated financial losses attributable to mastitis were reduced $(P<0.01)$ because of more milk-quality premiums and fewer losses attributable to mastitis.

Use of milk quality teams stimulated more improvement in herd performance for herds housed in stallbarns than for herds housed in freestalls (Table 6). Reduction of BMSCC and rate of clinical mastitis were greater $(P<0.031)$ in stallbarn than free stall herds. Operators of herds housed in stallbarns reported greater $(P<0.045)$ financial improvements compared with operators of herds housed in freestalls.

Herds that began the program having high BMSCC reported a 3 - to 5 -fold reduction $(P<0.007)$ in BMSCC at the end of the program than herds that began the program having medium and low BMSCC, respectively (Table 6). Herds that began the program having low BMSCC tended $(P=0.064)$ to reduce the amount of discarded milk because of clinical mastitis. Estimated rate of clinical mastitis and cost per clinical case decreased $(P<0.037)$ more for high BMSCC herds than for medium BMSCC herds. Milk quality premiums increased more $(P<0.001)$ for operators of high BMSCC herds than operators of medium and low BMSCC herds.

\section{DISCUSSION}

Herd operators that completed the team-based milk quality program recognized the importance of team for- 
Table 5. Monthly outcomes of 113 Wisconsin dairy farms completing the milk quality program.

\begin{tabular}{lcccc}
\hline Outcome & $\begin{array}{c}\text { Before } \\
\text { program }\end{array}$ & $\begin{array}{c}\text { After } \\
\text { program }\end{array}$ & Difference & $P$ \\
\hline Yield per cow per day, kg & 29.8 & 30.6 & 0.82 & 0.223 \\
Bulk milk SCC, cell/mL & 385,838 & 307,951 & $-77,887$ & $<0.001^{1}$ \\
Standard plate count, cfu/mL & 14,564 & 10,433 & -4131 & $0.014^{1}$ \\
Cows milked/h per person, no. & 31.6 & 30.6 & -0.95 & 0.606 \\
Milk discarded for clinical mastitis, d & 6.1 & 6.1 & 0.00 & 0.963 \\
Monthly clinical mastitis, ${ }^{2} \%$ & 6.8 & 4.9 & -1.9 & 0.016 \\
Monthly incidence of subclinical mastitis, ${ }^{3,5} \%$ & 10.9 & 9.2 & -1.8 & 0.033 \\
Monthly prevalence of subclinical mastitis, ${ }^{4,5} \%$ & 35.8 & 30.8 & -5.0 & 0.008 \\
Monthly cows culled for mastitis, ${ }^{6} \%$ & 1.4 & 0.8 & -0.7 & 0.023 \\
Monthly total cows culled, ${ }^{7} \%$ & 4.1 & -1.5 & 0.004 \\
Standard milk production loss per cow, ${ }^{8} \$$ & 3.88 & 2.75 & -1.12 & $<0.001$ \\
Bulk milk SCC current quality premium, $\$ / 45$ kg & 0.07 & 0.27 & 0.20 & $<0.001$ \\
Milk quality premium loss per cow, $\$$ & 9.21 & 5.97 & -3.24 & $<0.001$ \\
Standard loss from clinical mastitis per cow, ${ }^{9} \$$ & 7.71 & 5.47 & -2.24 & 0.010 \\
\hline
\end{tabular}

mation for improvement of milk quality. Most reported that they achieved their goals and wanted to continue team meetings after they completed the program. A high level of satisfaction related to the program may be because herd operators worked with their own teams on self-defined goals. Other studies have reported the influence of advisory teams on accomplishment of farm goals (Peters et al., 1994; Sischo et al., 1997; Weinand and Conlin, 2003). Dairy professionals can help producers implement and evaluate recommended management practices. In a previous study, 30 herd operators that worked with a team of extension professionals considered expert advice for problem solving and educational knowledge as the major benefits of the program (Peters et al., 1994).

In our study, herd operators that did not achieve their goals reported that a lack of time and other farm problems were the major constraints to implement changes. Similar barriers were reported by 35 herd operators working with diagnostic teams in Minnesota (Weinand and Conlin, 2003). Time, money, and facility restrictions accounted for $52 \%$ of the barriers. It is clear that farmers who enrolled in the program had a desire to improve milk quality because enrollment was voluntary. Implementation of changes, however, depended on their ability to apply changes to the current farm situation.
At the beginning of the program, milk quality premiums were reported to be the largest financial opportunity related to milk quality, and reduction of BMSCC was the most commonly cited goal. It is likely that herds focused on BMSCC and quality premiums because the program is based on improvement of those issues. Significant financial opportunities are related to improvements in BMSCC for dairy farms located in regions in which premiums are offered. In one study, Morin et al. (1993) reported that foregone milk-quality premiums accounted for 21 to $40 \%$ of the total loss associated with mastitis.

Environmental mastitis and changes in the milking routine were the critical factors most frequently selected as essential for improvements in milk quality. Environmental mastitis may have been identified most commonly because clinical signs were more common and risk for cow death compared with contagious mastitis. Milker training was identified less frequently as a critical area. Dairy farmers seem to be unaware of the importance of training for improving herd performance. According to Reneau (2001), motivation, and training of employees are essential to maintain consistent herd performance.

Reported goals were categorized as herd performance, procedures for mastitis control, and milking performance. In general, herds that enrolled in this 
Table 6. Monthly outcomes of 113 dairy farms completing milk quality program stratified by categories.

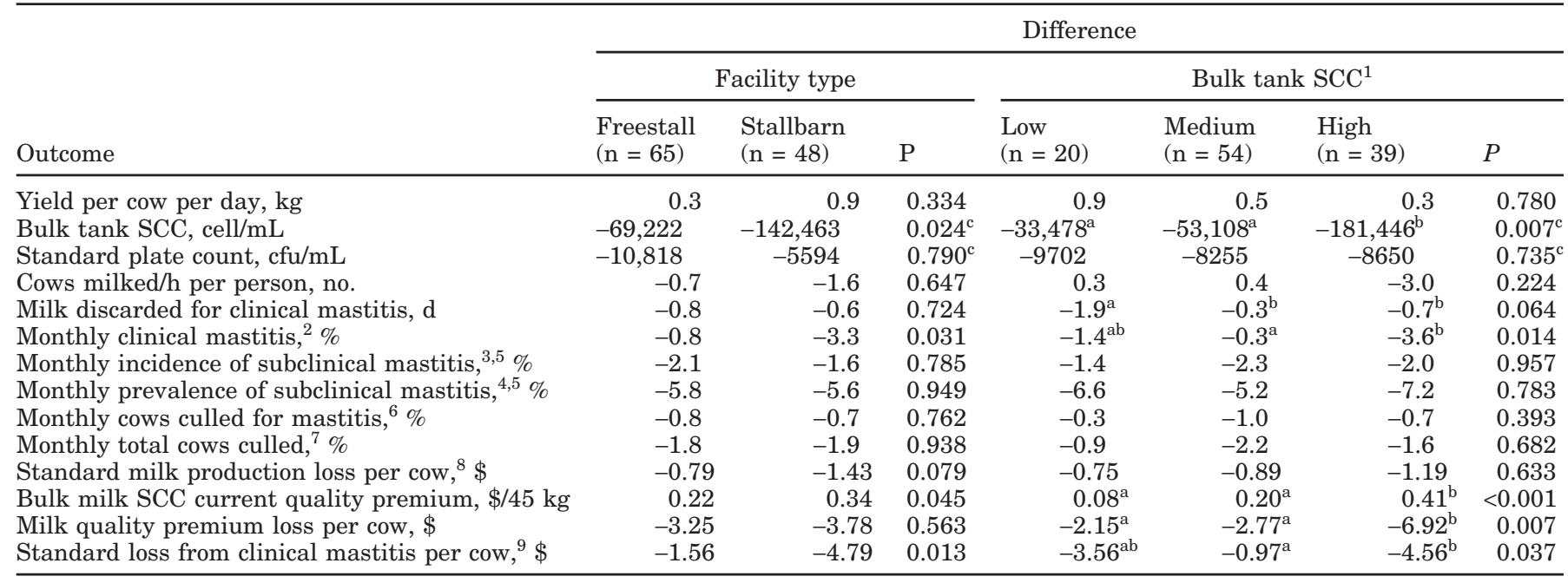

${ }^{a, b}$ Values having different superscripts for outcomes within category differ $(P \leq 0.05)$; ${ }^{c}$ Analyzed at $\log _{10}$.

${ }^{1}$ Bulk tank SCC: Low $=<250,000$ cell $/ \mathrm{mL}$; Medium $=250,000$ to 400,000 cells $/ \mathrm{mL}$; and High $=>400,000$ cells $/ \mathrm{mL}$.

${ }^{2}$ Reported monthly number of cases of clinical mastitis divided by the number of lactating cows.

${ }^{3}$ Percentage of cows with SCS $>4$ for the first time in current lactation.

${ }^{4}$ Percentage of cows with SCS $>4$ at current test.

${ }^{5}$ Calculated average for herds enrolled in DHI; 86 cows overall; freestall herds ( $\left.n=49\right)$; stallbarn herds $(n=37)$.

${ }^{6}$ Percentage of cows culled due to mastitis reason in previous month.

${ }^{7}$ Percentage of total cows culled in previous month.

${ }^{8}$ Total average milk production loss due to cows having greater SCS than the goal standard multiplied by the milk price. Calculated with fixed milk price of $\$ 0.24 / \mathrm{kg}$.

${ }^{9} \mathrm{Sum}$ of the total drug cost, discard milk cost, veterinary/labor cost due to clinical mastitis. Calculated with fixed prices (drug cost $\$ 15.00$, milk price $\$ 0.24 / \mathrm{kg}$, and veterinary/labor cost $\$ 50.00$ ).

program wanted to increase financial performance, reduce mastitis, and milk cows faster. Although operators of herds housed in stallbarns were more likely to have goals related to herd performance, operators of herds housed in freestalls were more likely to select goals related to procedures for mastitis control. As reported in the companion article (Rodrigues et al., 2005), cows housed in stallbarns began the program having smaller milk yields and greater BMSCC. As a result, herds housed in stallbarns may have placed greater priority for increasing herd performance than herds housed in freestalls. Similarly, differences in goals were reported based on BMSCC category. Herds that began the program having low BMSCC were less likely to have goals related to herd performance. Performance of low BMSCC herds was already acceptable so goals were focused on alternative areas such as general management, dry cow management, and teat health.

Many actions for controlling mastitis were related to milking activities and milk culture. Milking practices are important for udder health because they can reduce exposure to teat-end bacteria and reduce teat damage (Rasmussen, 2000). Microbiological analysis of milk obtained from the bulk tank, milk samples obtained from cows with clinical mastitis, and milk samples obtained from cows having high SCC were commonly reported. Teams used the results to define prevalent pathogens and to identify individual cow problems. Teams of herds housed in stallbarns were more likely to submit milk samples for culture than teams of herds housed in freestalls.

Overall, herds reported a high adoption of many recommended management practices including practices that were highly adopted before beginning the program. Formation of milk quality teams was successful in encouraging farms to adopt recommended management practices and improve communication between producers and dairy professionals. Sischo et al. (1997) previously reported that use of advisors was essential for success of a program that promoted rational use of antibiotics. In that study, farms that received visits from an advisory group reported a greater adoption of recommended practices than farmers that were not visited. Their study identified the occurrence of a poor relationship among veterinarians and clients as a risk factor for violative antibiotic residues. Their study confirms the importance of an integrated approach by farm advi- 
sors and dairy producers to solve dairy management problems.

Some recommended practices were adopted less frequently and at lesser rate by operators of herds housed in stallbarns than operators of herds housed in freestalls. Operators of herds housed in freestalls were more likely to adopt a written treatment protocol, a schedule for milking system analysis, and a training program for milking personnel. Herds housed in freestalls are usually larger than herds housed in stallbarns, and training and correct definition of tasks may have greater priority for these herd managers.

In our study, operators of herds that began the program having high BMSCC were more likely to adopt a complete milking routine and to plan milk quality with their veterinarian than were operators of herds that began the program with low BMSCC. Operators of herds that began with high BMSCC had more need to adopt recommended milking practices and plan for milk quality because they reported more problems related to mastitis.

Formation of a milk quality team and adoption of recommended management practices resulted in significant improvements in herd performance. Measures of clinical and subclinical mastitis were reduced and fewer cows were culled for mastitis at the end of the program. Participation in the milk quality program was successful in reducing BMSCC and increasing quality premiums. Overall, estimated losses of milk quality premiums were reduced. When herds reduced BMSCC, the quality premium that they received came closer to the premium that they would receive as they achieved their milk quality goals.

Herds that were housed in stallbarns showed more improvement during the milk quality program and had larger differences in herd performance than herds housed in freestalls. Greater prevalence of contagious pathogens, higher BMSCC, and reduced use of many recommended practices at the beginning of the program probably allowed more room for improvement in these herds. Morin et al. (1993) reported similar improvements in a herd having high BMSCC (mean BMSCC = 498,000 cells $/ \mathrm{mL}$ ) compared with 3 other herds participating in a mastitis control program. In that study, the mastitis control program was most efficacious and costeffective in the herd that began the program with higher BMSCC. In this study, herds that began the milk quality program having high BMSCC reported larger decreases in BMSCC and rate of clinical mastitis.

\section{CONCLUSIONS}

Formation of milk quality teams was helpful for improvements in mastitis control and to reduce losses associated with mastitis. Use of a team-based milk quality program was effective in encouraging adoption of recommended practices and improving milk quality.

\section{REFERENCES}

Barkema, H. W., Y. H. Schukken, T. J. Lam, M. L. Beiboer, H. Wilmink, G. Benedictus, and A. Brand. 1998. Incidence of clinical mastitis in dairy herds grouped in three categories by bulk milk somatic cell counts. J. Dairy Sci. 81:411-419.

Eberhart, R. J., L. J. Hutchinson, and S. B. Spencer. 1982. Relationship of bulk tank somatic cell counts to prevalence of intramammary infection and to indices of herd production. J. Food Prot. 45:1125-1128.

Fenlon, D. R., D. N. Logue, J. Gunn, and J. Wilson. 1995. A study of mastitis bacteria and herd management practices to identify their relationship to high somatic cell counts in bulk tank milk. Br. Vet. J. 151:17-25.

Giger, R., T. D. Carruthers, C. S. Ribble, and H. G. Townsend. 1994. A survey of veterinarian and producer perceptions of herd health services in the Saskatoon milkshed. Can. Vet. J. 35: 359, 362-366.

Harmon, R. J. 1994. Physiology of mastitis and factors affecting somatic cell counts. J. Dairy Sci. 77:2103-2112.

Jayarao, B. M., and D. R. Wolfgang. 2003. Bulk-tank milk analysis. A useful tool for improving milk quality and herd udder health. Vet. Clin. North Am. Food Anim. Pract. 19:75-92.

Morin, D. E., G. C. Petersen, H. L. Whitmore, L. L. Hungerford, and R. A. Hinton. 1993. Economic analysis of a mastitis monitoring and control program in four dairy herds. JAVMA 202:540-548.

Payne, M., C. M. Bruhn, B. Reed, A. Scearce, and J. O'Donnell. 1999. On-farm quality assurance programs: A survey of producer and industry leader opinions. J. Dairy Sci. 82:2224-2230.

Peters, R. R., E. K. Cassel, M. A. Varner, R. C. Eickelberger, L. R. Vough, J. E. Manspeaker, L. E. Stewart, and J. W. Wysong. 1994. A demonstration project of interdisciplinary dairy herd extension advising funded by industry and users. 1. Implementation and evaluation. J. Dairy Sci. 77:2438-2449.

Rasmussen, M. D. 2000. A review of milking preparation: The science. Pages 104-110 in Proc. Natl. Mastitis Counc., Atlanta, GA. Natl. Mastitis Counc., Inc., Madison, WI.

Reneau, J. K. 2001. Somatic cell counts: Measures of farm management and milk quality. Pages 29-37 in Proc. Natl. Mastitis Counc., Reno, NV. Natl. Mastitis Counc., Inc., Madison, WI.

Rodrigues, A. C. O., D. Z. Caraviello, and P. L. Ruegg. 2005. Management of Wisconsin dairy herds enrolled in milk quality teams. J. Dairy Sci. 88:2660-2671.

Ruegg, P. L. 2003. Investigation of mastitis problems on farms. Vet. Clin. North Am. Food Anim. Pract. 19:47-73.

Sargeant, J. M., Y. H. Schukken, and K. E. Leslie. 1998. Ontario bulk milk somatic cell count reduction program: Progress and outlook. J. Dairy Sci. 81:1545-1554.

SAS Institute. 2001. SAS/STAT, version 8.2 ed. SAS Inst., Inc., Cary, NC.

Sischo, W. M., N. E. Kiernan, C. M. Burns, and L. I. Byler. 1997. Implementing a quality assurance program using a risk assessment tool on dairy operations. J. Dairy Sci. 80:777-787.

Weinand, D., and B. J. Conlin. 2003. Impacts of dairy diagnostic teams on herd performance. J. Dairy Sci. 86:1849-1857. 